\title{
Koyun (Ovis aries) Solunum Sistemindeki Bronkus, Bronkulus ve Alveoler Hücrelerdeki AIA (Artocarpus integrifolia) ve PSA (Pisum sativum) Lektinlerinin Dağılımı
}

\author{
Kenan ÇINAR *1 (1) , Gülsüm MANAV 2 (D), Rovshan Jabbarov3 ${ }^{(1)}$ \\ 1,2,3Süleyman Demirel Üniversitesi, Fen Edebiyat Fakültesi, Biyoloji Bölümü, , Isparta, Türkiye
}

(Alınış / Received: 26.03.2019, Kabul / Accepted: 27.01.2020, Online Yayınlanma / Published Online: 20.04.2020)

Anahtar Kelimeler
Koyun,
Ovis aries,
Bronkus,
Bronkulus,
İmmunohistokimya,
Lektin

Anahtar Kelimeler

Ovis aries,

Bronkus,

İmmunohistokimya,

\section{Distributaion of AIA(Artocarpus integrifolia) and PSA (Pisum sativum) Lectins in Bronchus, Bronchulus and Alveolar Cells in Sheep (Ovis aries) Respiratory System}

\section{Keywords}

Sheep,

Ovis aries,

Bronchus,

Bronchulus,

Immunohistochemistry, Lectin
Özet: Bu çalışmada karbonhidratları spesifik ve geri dönüşümlü olarak tanıyan ve bağlanan, glikoproteinlerin çalışılmasında çok önemli bir potansiyel ve değere sahip, birçok fizyolojik ve patolojik süreçlerin anlaşılmasında aracı olan lektinlerden AIA ve PSA' nın koyun primer, sekonder, tersiyer bronkus, bronkulus verus ve bronkulus respiratoryuslarda immunohistokimyasal olarak lokalizasyonunun belirlenmesi amaçlandı. Sonuç olarak, solunum mukozası her zaman enfeksiyöz ajanlara maruz kaldığından, koyun akciğerinde bazı korunma sistemlerinin olduğu ve bu sistemlerden primer bronkuslarda lümene ulaşan kinosilyumlu hücrelerin apikal sitoplazmalarında, lümene ulaşmayan (bazal) hücrelerin lamina epitelyalis yüzeyinde, primer bronkuslarda seröz bez epiteline ait hücrelerin apikal sitoplazmalarında, tersiyer bronkusların lümene ulaşmayan (bazal) hücrelerinde ve lümene ulaşan hücrelerin apikal sitoplazmasında, bronkulus verusun ve bronkulus respiratoryusun lamina epitelyalis hücrelerinin yüzeyinde, alveolar makrofajlarda galaktoz/galaktozamin şeker rezidüeleri ve primer bronkusun lamina epitelyalis yüzeyinin mannoz/glukoz șeker rezidüeleri için spesifikleștiği, bunun da hayvan yetiștiriciliğine katkıda bulunacağı düşünülmektedir.

\begin{abstract}
In this study it was aimed to determination of immunohistochemical localization of primary, secondary, tertiary bronchus, bronchulus verus, bronchulus respiratorius of sheep (Ovis aries) with lectins which are very important potential and value in the study of glycoproteins, recognizing and binding carbohydrates specifically and reversibly, mediators of many physiological and pathological processes AIA and PSA. In conclusion, since the respiratory mucosa was always exposed to infectious agents it was found that there were some protection systems in the sheep lung and these systems are localized specifically for in the apical cytoplasm of the cells of the kinociliary cells that reach the lumen in the primary bronchus, on the surface of the lamina epithelial cells of the lumen (basal) cells, in the apical cytoplasm of the cells of the serous gland epithelium in the primary bronchus, in the (basal) cells of the tertiary bronchus and in the apical cytoplasm of the cells reaching the lumen, on the lamina epithelial surface of the bronchulus verus, on the surface of bronchus respiratory tract lamina epithelial cells, galactose/galactosamine sugar residues in alveolar macrophages and lamina epithelial surface of primary bronchulus are speculated for mannose/glucose sugar residues, which will contribute to animal agriculture.
\end{abstract}




\section{Giriş}

Solunum sistemi, bir çift akciğerden ve akciğerlere havayı ulaştıran bir seri hava yollarından oluşmaktadır. Akciğer içinde hava yolları, en küçük hava boşluğu olan alveollere ulaşıncaya kadar giderek küçülen tüplere dallanmaktadır [1]. Memeli akciğerinde, solunum yollarının selektif inflamatuar reaksiyonları, viral enfeksiyonlarla, transplant reddetme ve otoimmun hastalıklarla ilișkilendirilmektedir. $\mathrm{Bu}$ selektif reaktivitenin moleküler temeli bilinmese de, immünolojik süreçlerdeki karbonhidratların etkisi, dokuya özgü inflamatuvar reaksiyonlarda, zar glikokonjugatlarının potansiyel bir rolü olabileceğini göstermektedir [2]. İlk lektinin 1888' de keşfedilmesinden bu yana 100 yıldan fazla bir zaman geçti [3]. Eritrositlerdeki spesifikliği nedeniyle, Landsteiner, bitki hemaglütininlerinin eylemlerinin antikor reaksiyonlarına benzer olduğunu varsaydı; ancak, bunlar ne katalitik ne de orijinli bağışıklık değillerdi ve pek antikor olarak kabul edilemezlerdi [4]. Bu nedenle latince kelimeye dayalı seçmek anlamına gelen genel bir terim olan "Legere" immün kökenli olmayan tüm şekere özgü aglütininleri temsil etmesi için önerildi [5]. 1960' larda afinite kromatografisi uygulamasından bu yana çok sayıda lektin izole edilmiş̧ir [6-7]. Lektinlerle ilgili en önemli ve değerli bulgu, karbonhidratları spesifik ve geri dönüşümlü olarak tanımaları ve bağlamalarıdır. $\mathrm{Bu}$ özellik sayesinde lektinler, glikoproteinlerin çalışmasında muazzam bir potansiyel ve değere sahip ve birçok fizyolojik, patolojik süreçlerin mekanizmalarının anlaşılması kolaylaşmıştır. Örneğin, bakteri veya virüslerin konak hücrelere yapıșması, enfeksiyonların başlaması için bir önkoşuldur. E coli' nin bukkal epitel hücrelerine tutunma sürecinde, spesifik şeker reaksiyonları içerdiği bulundu. Tutunma mannozla inhibe edildiğinden Con A lektini ile ön işlemden geçirildikten sonra E. coli' nin epitel hücrelerine tutunmasını engelleyebileceği bildirilmiştir [8]. Bu gerekçelerle, mannozun reseptörü ile $E$. coli' nin ortak reseptör olduğu tespit edildi. Ayrıca, birçok başka bakteride spesifik șekerler farklı olsa da lektinkarbonhidrat reaksiyonları ile dokuya tutunmaktadır [9]. Son yllarda lektinlere olan ilgi, klinik ve biyokimyasal olmak üzere çok çeşitli biyolojik özellikleri ve uygulamaları nedeniyle artmaktadır [10]. Glikokonjugatların şeker kalıntıları solunum patojenleri için reseptör bölgesi olarak işlev görebilir [11]. Solunum sisteminde glikokonjugatlar, mukosillerin temizlenmesinde ve kanal savunmasında merkezi bir rol oynar [2].

\section{Materyal ve Metot}

$\mathrm{Bu}$ çalışmada 10 adet sağlıklı erişkin koyuna (Ovis aries) ait primer bronkus ve akciğer örnekleri materyal olarak kullanıldı. Alınan primer bronkuslar ve akciğer dokuları, Bouin solüsyonunda 16 saat süreyle tespit edildi. Daha sonra alkol serisinden
(\%50, \%70, \%80, \%90, \%100(I), \%100(II), $\% 100($ III)) geçirilerek dehidre edilen örnekler, ksilolde şeffaflaştırılarak parafine gömülüp bloklandı. Parafin bloklardan 5-6 $\mu$ m kalınlığında kesitler alındı. Alınan kesitlere genel yapının belirlenmesi için Masson' un Triple boyası yapıldı. Endojen peroksidazın tutulması için 10 dakika \%0,3'lük hidrojen peroksit $\left(\mathrm{H}_{2} \mathrm{O}_{2}\right)$ ile muamele edilen kesitler daha sonra distile su ile çalkalandı ve $0,1 \mathrm{M}$ ve $\mathrm{pH}$ 7,2'lik PBS (phosphate buffer saline) (Sigma P4417) içeren \%1'lik Bovine Serum Albumine (BSA) (Sigma A3311) ile yıkandı. Kesitler karbonhidrat özgünlüğü ve tür adlarının yanı sıra dilüsyon oranları da PBS içinde çözülen Horseradish Peroksidaz bağlı (HRP) lektinlerle 30 dakika oda sıcaklığında inkübe edilerek PBS ile yıkandı. HRP lektinlerle bağlantı içeren bölgelerin tespit edilmesi için kesitler DAB (3,3' diamino benzidine tetra hydricloride)' da (Sigma D0426) 10 dakika oda sıcaklığında inkübe edildi. Distile su ile yıkandıktan sonra alkol ve ksilollerden geçirilen kesitler entellan ile kapatıldı.

\section{Bulgular}

\subsection{Primer bronkus}

Primer bronkusun lümene ulaşan hücrelerin apikal sitoplazmalarında zayıf, lamina epitelyalis yüzeyi güçlü PSA reaksiyonu verirken, lümene ulaşmayan hücrelerde (bazal), goblet hücrelerinde, seröz ve müköz bez epiteline ait hücrelerin apikal sitoplazmalarında reaksiyona rastlanmadı (Şekil 1).

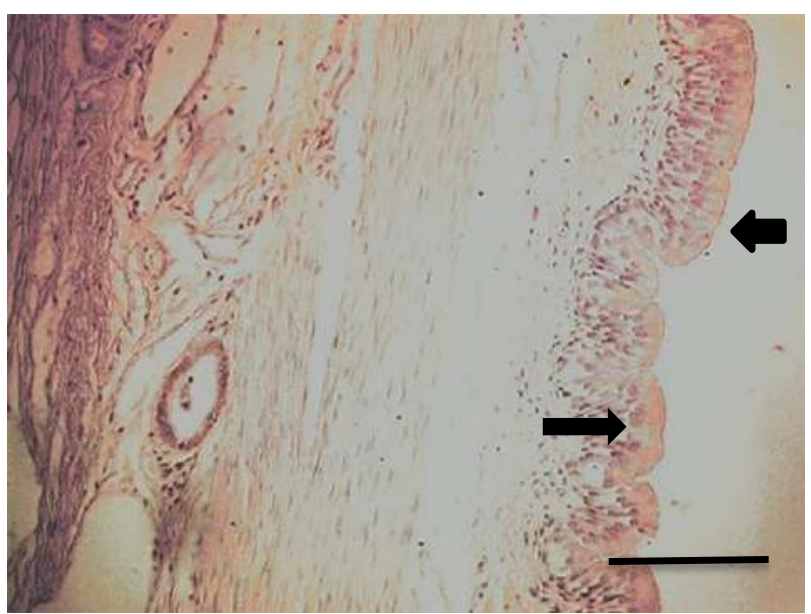

Şekil 1. Primer bronkus. Lamina epitelyalis yüzeyi (kalın ok) güçlü reaksiyon, lümene ulaşan kinosilyumlu hücrelerin apikal sitoplazmaları (ince ok) zayıf reaksiyon. PSA. Bar: 50 $\mu \mathrm{m}$.

Lümene ulaşan kinosilyumlu hücrelerin apikal sitoplazmalarında, lümene ulaşmayan (bazal) hücrelerde, lamina epitelyalisin yüzeyinde çok güçlü (Şekil 2), seröz bez epiteline ait hücrelerin apikal sitoplazmalarında çok güçlü, goblet hücrelerinde orta yoğunlukta ve müköz bez epiteline ait hücrelerin apikal sitoplazmalarında zayıf AIA reaksiyonu saptandı (Şekil 3). 


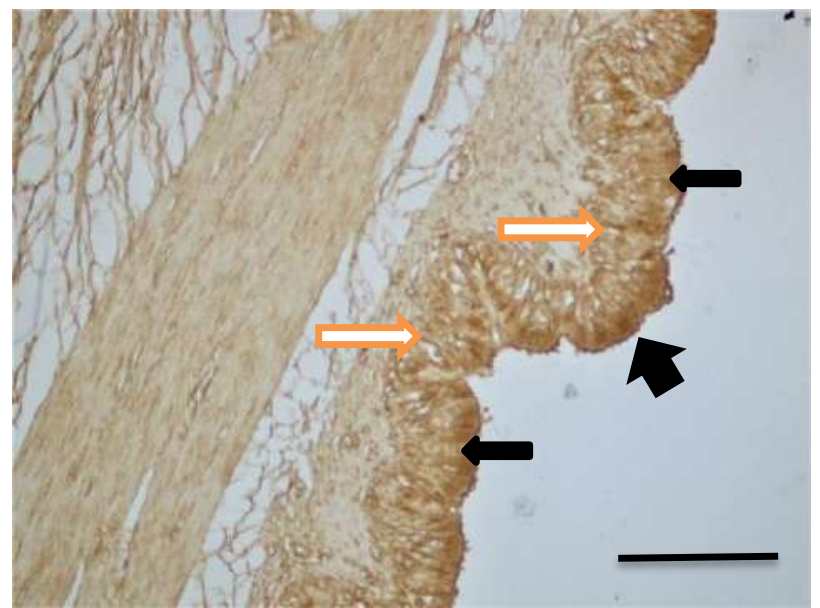

Şekil 2. Primer bronkus. Lamina epitelyalis yüzeyi (siyah kalın ok), bazal hücreler (beyaz oklar), lümene ulaşan kinosilyumlu hücrelerin apikal sitoplazmalarında (ince siyah oklar) çok güçlü reaksiyon. AIA. Bar: $50 \mu \mathrm{m}$.

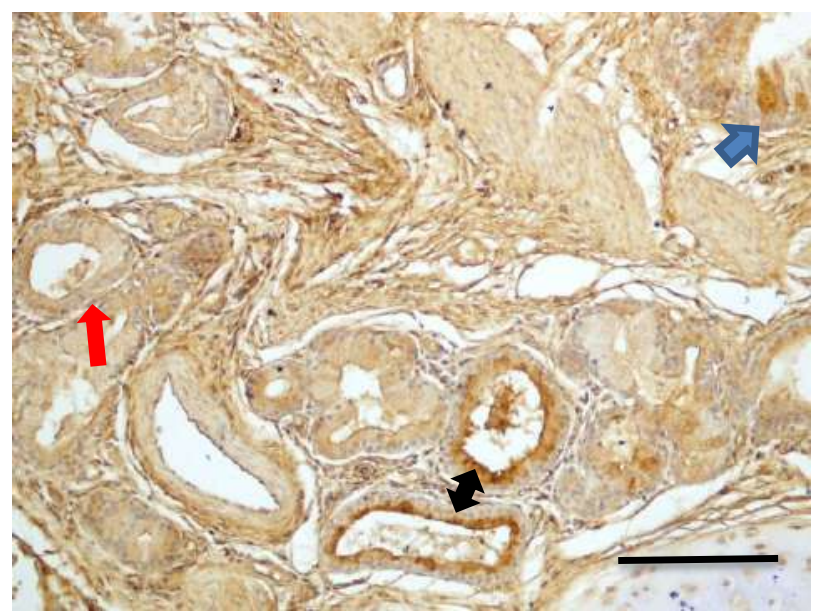

Şekil 3. Primer bronkus. Seröz bez epiteline ait hücrelerin apikali (çift yönlü siyah ok) çok güçlü reaksiyon, müköz bez epiteline ait hücrelerin apikalinde (kırmızı ok) zayıf reaksiyon, goblet hücresinde (mavi ok) orta yoğunlukta reaksiyon AIA. Bar: $50 \mu \mathrm{m}$.

\subsection{Sekonder bronkus}

AIA uygulamasında lamina epitelyalisin yüzeyinde ve goblet hücrelerinde güçlü, lümene ulaşan kinosilyumlu hücrelerin apikal sitoplazmasında ve lümene ulaşmayan (bazal) hücrelerde orta yoğunlukta (Şekil 4) reaksiyon saptandı. Seröz ve müköz bezlere ait hücrelerin apikalinde ise reaksiyona rastlanmadı. PSA uygulamasındaysa lümene ulaşan kinosilyumlu hücrelerin apikal sitoplazmasında ve lamina epitelyalisin yüzeyinde zayıf reaksiyon saptanırken, goblet hücrelerinde, lümene ulaşmayan (bazal) hücrelerde, seröz ve müköz bezlere ait hücrelerin apikalinde reaksiyona rastlanmadi.

\subsection{Tersiyer bronkus}

Lümene ulaşmayan (bazal) hücrelerde ve lümene ulaşan hücrelerin apikal sitoplazmasında güçlü (Şekil 5), bazı kondroblastlarda orta yoğunlukta AIA reaksiyonu saptanırken, tersiyer bronkusta bu bölgeler için PSA reaksiyonuna rastlanmadı.

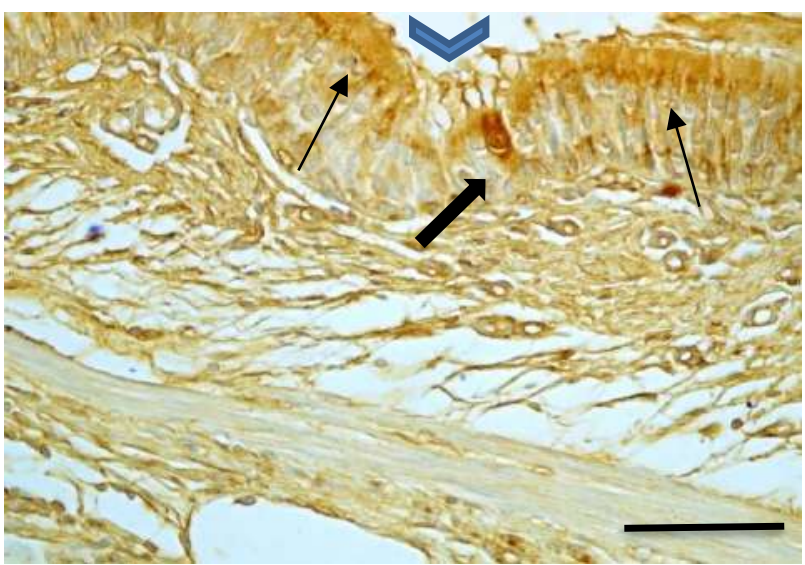

Şekil 4. Sekonder bronkus. Goblet hücreleri (siyah kalın ok), lamina epitelyalisin yüzeyi (mavi ok) güçlü, bazal hücrelerde (ince, kısa oklar) ve lümene ulaşan kinosilyumlu hücrelerin apikal sitoplazmasında orta yoğunlukta (ince uzun oklar) reaksiyon. AIA. Bar: $50 \mu \mathrm{m}$.

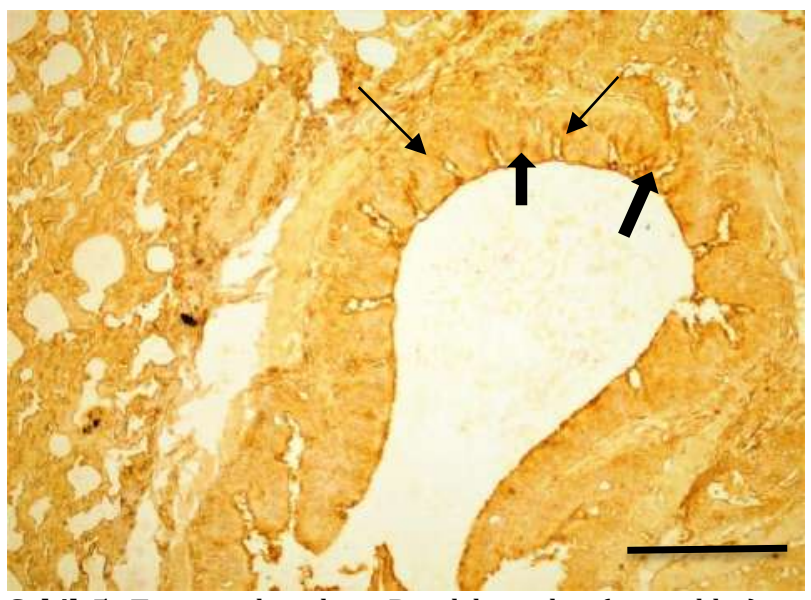

Şekil 5. Tersiyer bronkus. Bazal hücreler (ince oklar) ve lümene ulaşan kinosilyumlu hücrelerin apikal sitoplazmaları (kalın oklar) güçlü reaksiyon. AIA. Bar: 50 $\mu \mathrm{m}$.

\subsubsection{Bronkulus verus (terminal bronkulus)}

Lamina epitelyalis yüzeyinde ve apikal sitoplazmada zayıf PSA reaksiyonu gözlendi (Şekil 6). Bronkulus verus' un lamina epitelyalis yüzeyinde güçlü, bazı epitel hücrelerinde daha yoğun AIA reaksiyonu izlenirken, apikal sitoplazmada zayıf AIA reaksiyonu saptandı (Şekil 7).

\subsubsection{Bronkulus respiratoryus (bronkulus alveolaris)}

Epitel hücrelerinin yüzeyinde güçlü, hücre sitoplazmalarında ise orta yoğunlukta PSA reaksiyonu gözlendi (Șekil 8). Lamina epitelyalis hücrelerinin yüzeyinde çok güçlü, hücre sitoplazmalarında orta yoğunlukta AIA reaksiyonu saptandı (Şekil 9).

\subsection{Alveol}

Alveollerde Pnömosit II hücresinde PSA orta derecede reaksiyon verirken (SSekil 10), AIA reaksiyonu zayıf olarak gözlendi (Şekil 11). Alveolar makrofajlarda AIA lektiniyle güçlü reaksiyon saptanırken (Şekil 12), orta derece PSA lektini reaksiyonu tespit edildi (Şekil 13). 


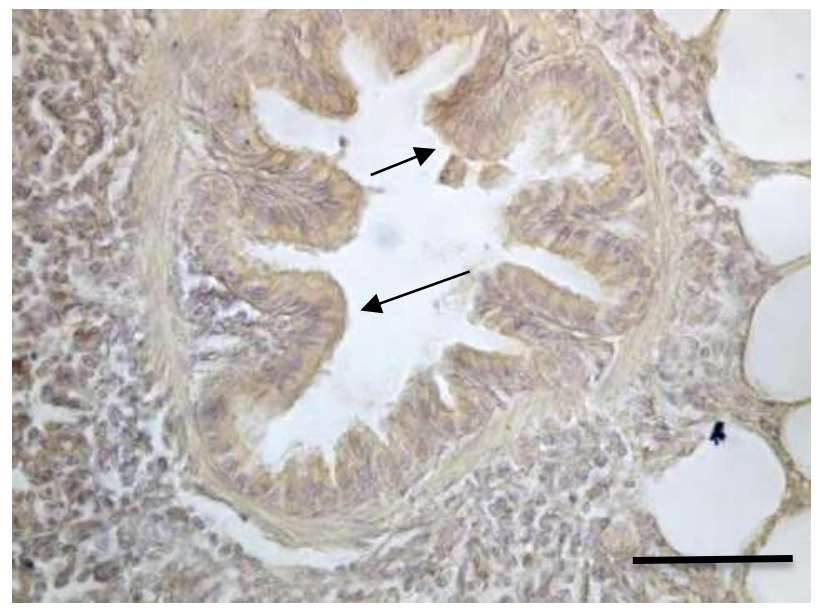

Şekil 6. Bronkulus verus. Lamina epitelyalis yüzeyinde (oklar) zayıf reaksiyon. PSA. Bar: $50 \mu \mathrm{m}$.

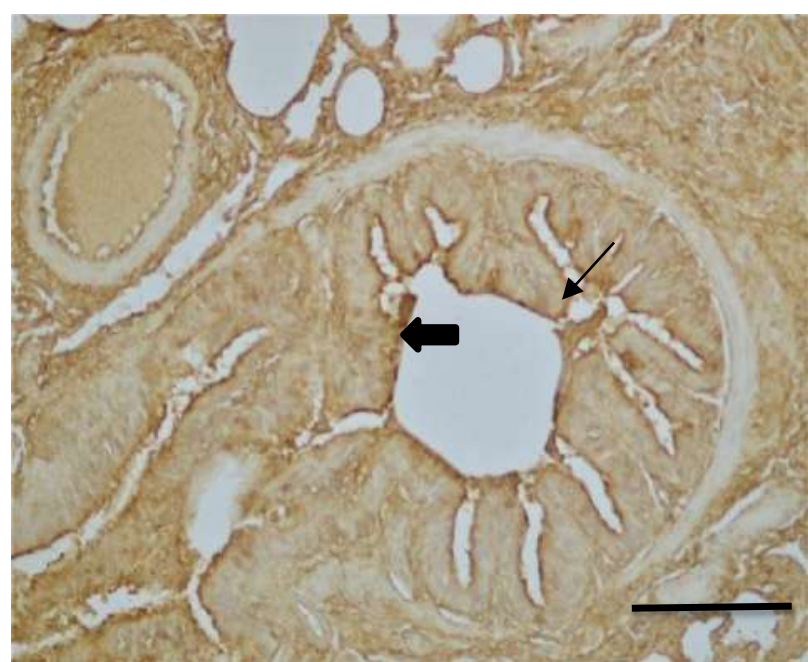

Şekil 7. Bronkulus verus. Apikal sitoplazmada (kalın ok) zayıf, lamina epitelyalis yüzeyinde (ince ok) güçlü reaksiyon AIA. Bar: $50 \mu \mathrm{m}$.

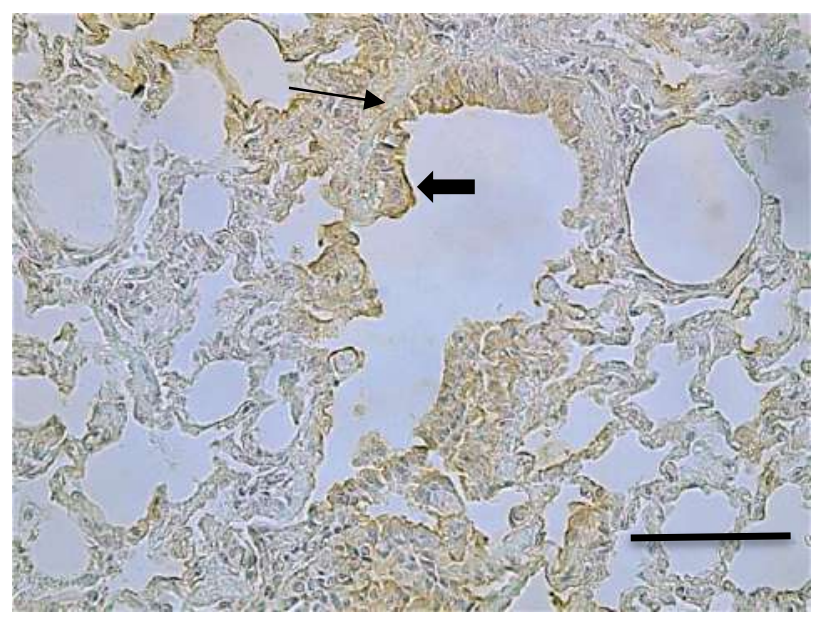

Sekil 8. Bronkulus respiratoryus. Lamina epitelyalis yüzeyinde (kalın ok) güçlü ve sitoplazmalarında (ince ok) orta yoğunlukta reaksiyon. PSA. Bar: $50 \mu \mathrm{m}$.

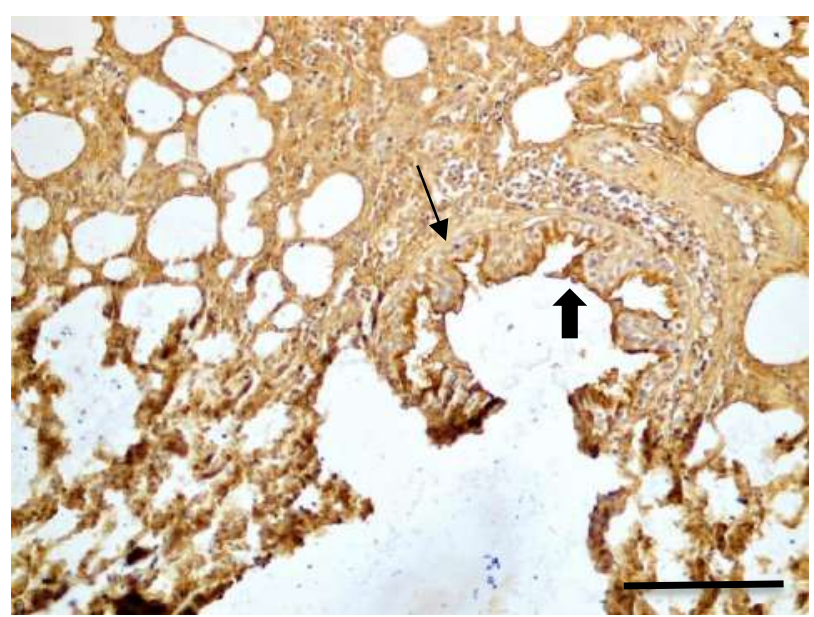

Şekil 9. Bronkulus respiratoryus. Epitel hücrelerinin yüzeyinde (kalın ok) çok güçlü, apikal sitoplazmalarda (ince ok) orta yoğunlukta reaksiyon. AIA. Bar: $50 \mu \mathrm{m}$.

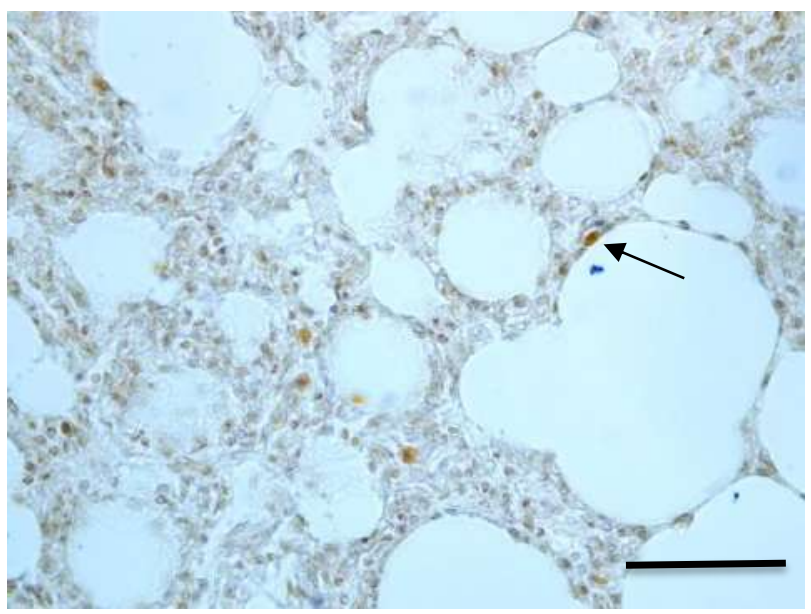

Şekil 10. Alveoller. Pnömosit II' de (ok) orta yoğunlukta reaksiyon. PSA. Bar: $50 \mu \mathrm{m}$.

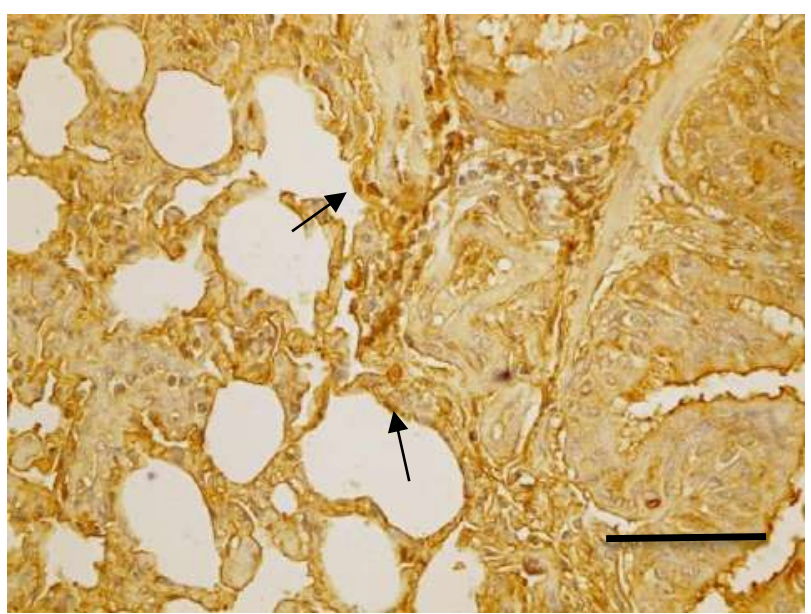

Şekil 11. Alveoller. Pnömosit II de (oklar) zayıf reaksiyon. AIA. Bar: $50 \mu \mathrm{m}$. 


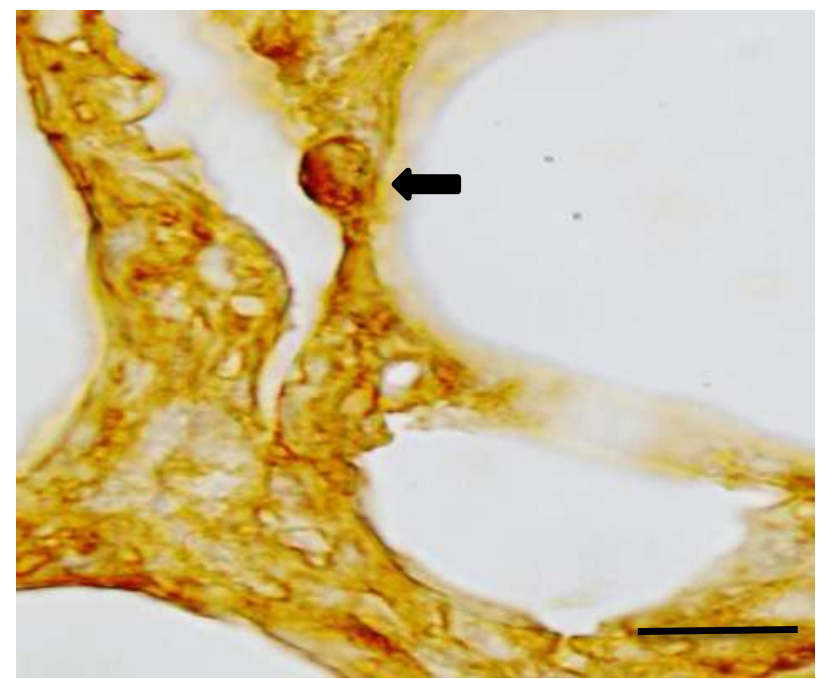

Şekil 12. Alveolar makrofajda (ok) güçlü reaksiyon. AIA. Bar: $50 \mu \mathrm{m}$.

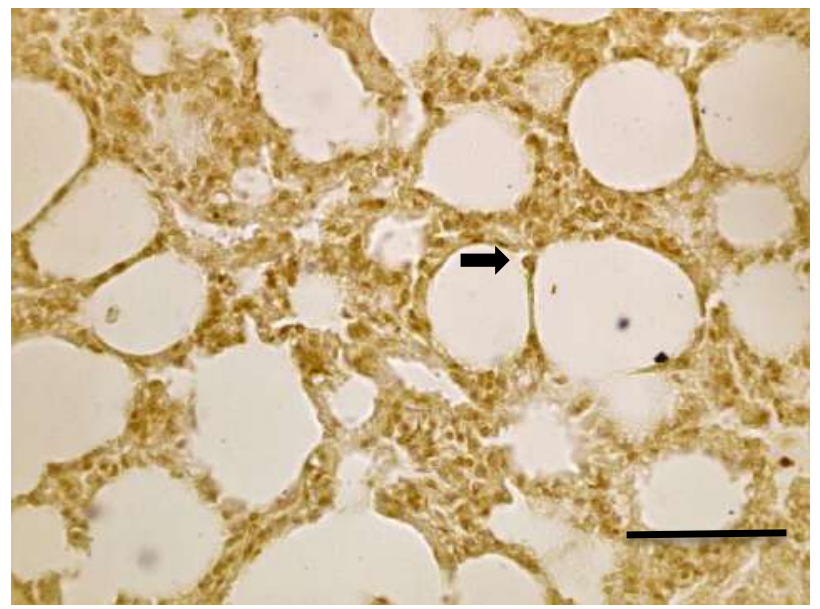

Şekil 13. Alveolar makrofajda (ok) orta derecede reaksiyon. PSA. Bar: $50 \mu \mathrm{m}$.

\section{Tartışma ve Sonuç}

100 yıldan daha uzun bir süre önce keşfedilen ve belirli karbonhidrat yaplarını seçici olarak tanıma yetenekleri ile tanımlanmış olan lektinler, canlı organizmalarda her yerde bulunur. Kesin işlevleri henüz yeterince keşfedilmemiş ve tam olarak anlașılmamıștır ancak bağlayıcı ortakların tanınması, hücre kimliği, adezyon, sinyalleşme, büyüme düzenlemesi, sağlık ve hastalık konularında yer alan sayısız biyolojik mekanizma içinde açlkça yer almaktadır. "Şeker kodunu" anlamak, mevcut biyolojik araştırmaların en önemlisidir.

Lektinler hücre ve dokulardaki glikosilasyonu haritalamak için histokimyasal çalışmalarda yaygın olarak kullanılmaktadır [10]. Sağlıklı ve pnömoni hastalığı olan hindilerde (Meleagris gallopavo) yapılan çalışmada, sağlıklı hindilerin primer ve sekonder bronkuslarının lamina propriya ve tunika adventisyasında güçlü pozitif PSA reaksiyonu saptanırken akut pnömonili hindilerin akciğerindeki dejenere epitel ve adventisyal liflerde lektin boyama yoğunluğunun azaldığı ya da düzensiz ve zayıf reaksiyon gözlendiği bildirilmişitir [11].
Bu çalışmada primer bronkusun lamina epitelyalis hücrelerinin yüzeyinde güçlü Pisum sativum lektini reaksiyonu, sekonder bronkusun lamina epitelyalisinde ise zaylf Pisum sativum lektini reaksiyonu saptand.

$\mathrm{Bu}$ çalışmada primer bronkusun seröz bez epiteline ait hücrelerin apikal sitoplazmalarında çok güçlü, goblet hücrelerinde orta yoğunlukta ve müköz bez epiteline ait hücrelerin apikal sitoplazmalarında zayıf AIA reaksiyonu saptandı. Sekonder bronkusun goblet hücrelerinin AIA ile güçlü pozitif reaksiyon verirken, seröz ve müköz bezlere ait hücrelerin apikalinde reaksiyona rastlanmadı. İnsan hava yollarına ait kinosilyumlu epitel, bazal epitel hücrelerine yönelik yapılan çalışmalarda [12-13] AIA lektininin apikal yüzeye bağlandığını, bazı epitel hücrelerinde (kinosilyumlu hücreler) ve ağırlıklı olarak salgı hücrelerinde güçlü reaksiyon verdiği bildirilmiştir.

Endoskopik konfokal floresan mikroskobisine dayanan yeni akciğer görüntüleme tekniğiyle in vivo olarak normal ve zarar verilmiş rat akciğerinde yapılan çalışmada mannoz parçaları için karbonhidrat afinitesine sahip PSA lektininin bazı Tip I epitel hücreleri ve alveolar makrofajların hücre zarı reaksiyonlarının karakteristik olarak gerçekleştiği bildirilmiştir [14]. Bu çalışmada, alveolar makrofajlarda orta derecede PSA reaksiyonu saptandı.

$\mathrm{Bu}$ çalışmada primer bronkusun lamina epitelyalis yüzeyinde güçlü PSA ve sekonder bronkusun lamina epitelyalis yüzeyinde zayıf PSA reaksiyonu gözlendi. Primer ve sekonder bronkusların goblet hücrelerinde ve lümene ulaşmayan (bazal) hücrelerde PSA reaksiyonu saptanmadı. Primer bronkusun lümene ulaşan kinosilyumlu hücrelerin apikal sitoplazmalarında güçlü, sekonder bronkusun lümene ulaşan kinosilyumlu hücrelerin apikal sitoplazmasında zayıf PSA reaksiyonu saptandı. Primer bronkusun lümene ulaşan kinosilyumlu hücrelerin apikal sitoplazmalarında ve lümene ulaşmayan hücrelerde çok güçlü reaksiyon gözlendi. Goblet hücrelerinde ise orta yoğunlukta AIA reaksiyonu saptandı. Koyunların koku ve solunum mukozası üzerine lektin histokimyasal olarak yapılan çalışmada AIA ve PSA lektinlerine karşı epitelyumda, goblet hücrelerinde, lümene açılmayan hücrelerde ve kinosilyumlu hücrelerde reaksiyon gözlenmediği bildirilmiştir [15]. Koyun hava yolu epiteli üzerine ifade edilmiş membran glikokonjugatlarına yönelik yapılan lektin histokimyasal çalışmada PSA lektini için bronkus ve bronkulus epitelinde ve alveolar duvarda minimal düzeyde reaksiyon verdiği bildirilmiştir [2]. Bu çalısmada primer bronkusların ve bronkulus respiratoryusun lamina epitelyalis yüzeyinde güçlü, sekonder bronkusların ve bronkulus verusun lamina epitelyalis yüzeyinde zayıf PSA reaksiyonu gözlendi. 
Sağlıklı gönüllülerden ve intersitisyel akciğer hastalarından elde edilen hücrelerle, bu hücrelerin lektin bağlama özelliklerini karşılaştırarak bronkoalveolar lavaj türevli bazal veriler oluşturulmuştur. Alveolar makrofajlarda (AM) hücre yüzeyi glikokonjugat ekspresyonunu belirlemek için florokrom bağlı bitki lektinlerinden oluşan bir panel ve bunların AM' ye bağlanmasını belirlemek için de akış sitometrisi kullanılmıştır. Normal gönüllülerde, alveolar makrofajlarda PSA ve AIA pozitif reaksiyon gözlendiği bildirilmiștir [16]. Bu çalıșmada da alveolar makrofajlarda orta derecede PSA, güçlü AIA lektini reaksiyonu tespit edildi.

Histolojik anormallikleri ve akciğer hastalığı ile ilgili klinik belirtileri olmayan sağlıklı insanlarda akciğer ile yapılan çalışmada, kapillar endotelyal, Tip I ve Tip II hücrelerinde PSA lektini ile reaksiyon saptanmazken, seröz hücrelerde, alveolar makrofajlarda, vasküler endotelyal hücrelerinde PSA lektini ile orta dereceli reaksiyon tespit edildiği bildirilmiştir [17]. $\mathrm{Bu}$ çalışmada ise primer ve sekonder bronkusların lamina epitelyalis yüzeyinde güçlü, alveolar makrofajlarda ve pnömosit II (Tip II) hücresinde orta derecede PSA reaksiyonu saptandı.

$\mathrm{Bu}$ çalışmada, primer, sekonder, tersiyer bronkus, bronkulus verus, bronkulus respiratoryus ve alveol duvarında mannoz/glukoz ve galaktoz/galaktozamin reseptörleri için bölgesel olarak farklı reaksiyonlar tespit edildi.

Sonuç olarak, solunum mukozası her zaman enfeksiyöz ajanlara maruz kaldığından, koyun akciğerinde bazı korunma sistemlerinin olduğu ve bu sistemlerden primer bronkuslarda lümene ulaşan kinosilyumlu hücrelerin apikal sitoplazmalarında, lümene ulaşmayan (bazal) hücrelerin lamina epitelyalis yüzeyinde, primer bronkuslarda seröz bez epiteline ait hücrelerin apikal sitoplazmalarında, tersiyer bronkusların lümene ulaşmayan (bazal) hücrelerinde ve lümene ulaşan hücrelerin apikal sitoplazmasında, bronkulus verusun lamina epitelyalis yüzeyinde, bronkulus respiratoryusun lamina epitelyalis hücrelerinin yüzeyinde, alveolar makrofajlarda galaktoz/galaktozamin şeker rezidüeleri ve primer bronkusun lamina epitelyalis yüzeyinin mannoz/glukoz şeker rezidüeleri için spesifikleștiği, bunun da hayvan yetiștiriciliğine katkıda bulunacağı düşünülmektedir.

\section{Kaynakça}

[1] Baykal, B. ed. 2014. Histoloji Konu Anlatımı ve Atlas. Palme Yayıncilık, Ankara, 676-678s.

[2] Abdı, K., Kozbık, L., Lı, X., Menızr, S. J. 1994. Membrane Glycoconjugates Expressed on Sheep Airway Epithelium. The journal of Histochemistry and Cytochemistry, 42(10), 1341-1347.
[3] Sumner, J. B., Howell, S. F. 1936. Identification of Hemagglutinin of Jack Bean with Concanavalin A. J Bacteriol, 32(2), 227-237.

[4] Landsteiner, K. 1962. The Specificity of Serological Reactions. Agglutination. Dover Publications, New york, 246s.

[5] Lam, S. K., Ng, T. B. 2011. Lectins: Production and Practical Applications. Applied Microbiology and Biotechnology, 89, 45-55.

[6] Vretblad, P. 1976. Purification of Lectins by Biospecific Affinity Chromatography. Biochimica et Biophysica Acta (BBA)-Protein Structure, 169-176.

[7] Dan, X., Liu, W., Ng, T. B. 2016. Development and Applications of Lectins as Biological Tools in Biomedical Research. Medicinal Research Reviews, 221-247.

[8] Ofek, I., Mirelman, D., Sharon, N. 1977. Adherence of Escherichia coli to Human Mucosal Cells Mediated by Mannose Receptors. Nature, 623-625.

[9] Sharon, N., Lis, H. 2004. History of Lectins: From Hemagglutinins to Biological Recognition Molecules. Glycobiology, 53-62.

[10] Islam, F., Gopalan, V., K-Y Lam, A., Kabir, S. R. 2018. Pea Lectin Inhibits Cell Growth by Inducing Apoptosis in SW480 and SW48 cell lines. International Journal of Biological Macromolecules. 1(117), 1050-1057.

[11] Gyimah, I. E., Panigraphy, B. 1988. AdhesinReceptor Interactions Mediating the Attachment of Pathogenic Escherichia coli to Chicken Tracheal Epithelium. Avian Dis 32, 74-78.

[12] Dorscheid, D. R., Conforti, A. E., Hamann, K. J., Rabe, K. F., White, S. R. 1999. Characterizationof Cell Surface Lectin-Binding Patterns of Human Airway Epithelium. Histochemical Journal, 31(3), 145-151.

[13] Yi, S. M., Harson, R. E., Zabner, J., Welsh, M. J. 2001. Lectin Binding and Endocytosis at the Apical Surface of Human Airway Epitelia. Gene Therapy, 1826-1832.

[14] Chagnon, F., Fournier, C., Charette, P. G., Moleski, L., Payet, M. D., Dobbs, L. G., Lesur, O. 2010. In Vivo Intravital Endoscopic Confocal Fluorescence Microscopy of Normal and Acutely Injured Rat Lungs. Laboratory Investigation, 90, 824-834.

[15] Ibrahım, D., Nakamuta, N., Tanıguchı, K., Yamamoto, Y., Tanıguchı, K. 2014. Histological and Lectin Histochemical Studies on the Olfactory and Respiratory Mucosae of the Sheep. Journal of Veterenary Medical Science. 76(3), 339-346. 
[16] Meyer, K. C., Powers, C., Rosentha, N., Auerbach, R. 1993. Alveolar Macrophage Surface Carbohydrate Expression Is Altered in Interstitial Lung Disease as Determined by Lectin-binding Profiles. American Review of Respiratory Disease, 1325-1334.
[17] Barkhordari, A., Stoddart, W., McClure, F., McClure, J. 2004. Lectin Histochemistry of Normal Human Lung. Journal of Molecular Histology 35(2), 147-156. 